\title{
乳化系におけるリン脂質の酸化防止効果
}

\author{
渡邊 将人・原＼cjkstart節子・戸谷洋一郎 \\ 成蹊大学工学部（干180 東京都武蔵野市吉祥寺北町 3-3-1)
}

\section{Antioxidative Effects of Phospholipids in an Emulsifying System}

\author{
Masato Watanabe, Setsuko Hara, and Yoichiro Totani \\ Faculty of Engineering, Seikei University \\ (3-1 Kichijoji-kitamachi 3, Musashino-shi, Tokyo, $=180$ )
}

\begin{abstract}
The antioxidative activity and synergistic effects toward mixed tocopherol (Toc) of phosphatidylcholine (PC), phosphatidylethanolamine (PE) and PC concentrated phospholipid (PC-70) prepared from soy phospholipid were investigated using an emulsifying system of refined fish oil/water $=3 / 7$ under the autoxidation condition at $30^{\circ} \mathrm{C}$.

The antioxidative activity of each phospholipid increased along with the addition amount, and PC activity was the highest in phospholipids tested.

Synergistic effects toward Toc were remarkable with $20 \%$ phospholipid addition to the oil substrate, followed by $10 \%>5 \%>1 \%$, and PE showed the excellent synergistic effect in any level added than those of corresponding $\mathrm{PC}$ and PC-70 levels.

The antioxidative activity of phospholipid was stronger in the presence of water-soluble radical initiator than in the oil-soluble radical initiator.
\end{abstract}

Key words : antioxidant, synergist, phospholipid, autoxidation, tocopherol

\section{1 緒 論}

油糧資源にそしい我が国の主要な油脂資源である魚油 には生理活性に優れたイコサペンタエン酸 (EPA) やド コサヘキサエン酸 $(\mathrm{DHA})$ のような高度不飽和脂肪酸 (PUFA) が豊富に含まれている1),2)。しかし，抗血栓 作用, 制がん作用, 学習機能向上作用, 抗アレルギー作 用, 血中脂質低下作用, 網膜反射機能向上作用, 血圧降 下作用などの生理活性を持つ PUFA は酸化に対して非 常に不安定である。従来, マーガリンやショートニング などの原料として魚油の水素添加が行われているが, 生 成した硬化油は高い酸化安定性を得る代わりに, PUFA の生理機能を失っている。それ故, PUFA の健康 補助食品, 医薬品, 化粧品, 飼料などへの利用を図る上 で，効果的な酸化防止策を開発する必要がある ${ }^{3), 4) 。 ~}$

これまでの油脂の自動酸化や酸化防止に関する研究は ほとんど非水系で検討されたものであるが, 実際に油脂 を利用する場合に, 油脂が水亡共存する機会は非常に多 い。非水系における不飽和油脂の酸化速度, 酸化機構あ るいはその防止に関する知見は PUFA の利用や安全な

連絡者 : 戸谷洋一郎
供給を図る上で不可欠なるのであるが，それらの情報を 直接的に水共存系における PUFA の酸化挙動の予測に 適用することは難しい。

その一例として, Miyashita $5^{5), 6)}$ は非水系におい て酸化安定性に欠ける PUFA を希薄な濃度で水溶液に 分散させた場合, 非水系の場合と異なり, EPA や DHA のような PUFA ほど酸化安定性が増すことを報 告している。従って, 脂質の水共存系における酸化安定 性を種々の条件下に評価することは PUFA 含有製品の 品質管理の面から重要と考えられる。

本研究においては, PUFA と水が共存した系として 乳化系における魚油の自動酸化およびリン脂質の酸化防 止挙動について, 種々のリン脂質クラスを用いて検討す ると共に, リン脂質のトコフェロール (Toc) に対する 相乗効果を併せて検討した。

\section{2 実 験}

\section{$2 \cdot 1$ 試料と試薬}

自動酸化基質として, ミョシ油脂(株)より提供された 脱酸魚油を用いた。なお，自動酸化に先だって魚油に含 まれる酸化防止剂と微量の過酸化物を除去するために力 
ラム分画を行った。すなわち，国産化学(株)製カラムク ロマトグラフィー用シリカゲル (100 mesh) と日清製油 (株)から提供されたセライト (150〜200 mesh) を 5/1 $\mathrm{wt} / \mathrm{wt}$ の割合で混合し, $130^{\circ} \mathrm{C} て ゙ 3 \mathrm{~h}$ 活性化した後に, ヘキサンを用いてスラリー状にして, $46 \mathrm{mmi} . \mathrm{d} . \times 500$ $\mathrm{mm}$ のガラスカラムに $240 \mathrm{~g}$ 充填したものに魚油 $20 \mathrm{~g}$ を負荷して, ヘキサン/ジエチルエーテル (85/15 wt/ wt）を用いて精製魚油を分画した。

リン脂質は日清製油(株)より提供されたホスファチジ ルコリン $(\mathrm{PC})$ を約 $70 \%$ 含む $\mathrm{PC}$ 濃縮大豆リン脂質 (PC-70, 組成: PC $67.2 \%$, PE 14.5\%, PI 2.1\%, その 他 $16.2 \%$ ) と $\mathrm{PC}$ を約 $30 \%$ 含む精製大豆リン脂質 (PC -30 , 組成: PC $29.1 \%$, PE 23.9\%, PI 8.2\%, その他 $38.8 \%$ ）をアセトン分画 ${ }^{7)}$ して酸化防止剂と遊離脂肪酸 を除去した後に, 高純度の PC とホスファチジルエ夕 ノールアミン $(\mathrm{PE})$ を調製した。すなわち, 高純度 $\mathrm{PC}$ の調製に際しては, 上述のように準備したシリカゲルカ ラムに, アセトン分画後の $20 \mathrm{~g}$ の PC-70 を負荷した 後, クロロホルムーメタノール系溶媒の組成を $7 / 1 \rightarrow 4 / 1$ $\rightarrow 1 / 1 \rightarrow 1 / 2 \mathrm{vol} / \mathrm{vol}$ と順次変化させ, $50 \mathrm{~mL}$ ずつ分画 した区分を TLC-FID 分析して PC (純度 : 98.7\%) を 回収した。高純度 PE の調製に際しては, アセトン分画 後の PC-30 を同様にシリカゲルカラム分画を行い, 純 度 $91.2 \%$ の $\mathrm{PE}$ を得た。魚油に対するリン脂質の酸化 防止作用を検討する際に, リン脂質添加基質と対照実験 系の脂肪酸組成を等しくするために，必要に応じて対照 実験系に日清製油(株)製の大豆油を精製魚油の場合と同 様に精製した後, 所定量添加した。Tocに対するリン 脂質の相乗作用を検討するために, 日清製油(株)製 Toc 混合物 $(\alpha$-体 : $21.0 \%, \beta$-体 : $2.0 \%, \gamma$-体 : $58.0 \%, \delta$-体 : 19.0\%）を使用した。また，高速液体クロマトグラ フィー (HPLC) による Toc 定量用の内部標準物質とし

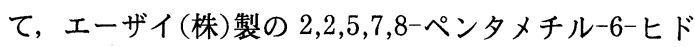
ロキシクロマン $(\mathrm{PMC})$ を用いた。

乳化系の自動酸化基質を調製するに当たっては, 乳化 剤として小宗化学(株)製の Tween\#20 を使用した。 HPLC 分析を行う場合は国産化学(株)製の HPLC 用へ キサンと2-プロパノールを用いたが, その他の試薬は すべて市販の特級品を使用した。

\section{$2 \cdot 2$ 乳化系自動酸化基質の調製}

Miyashita $ら^{5), 6)}$ の脂質一水共存系よりも工業的実用 に即した系を想定して, 脂質量を増やした乳化条件下に おける脂質の自動酸化挙動とリン脂質の酸化防止効果を 明らかにするために, 予備実験で最も長期間安定した $\mathrm{O} / \mathrm{W}$ 型乳化系を作ることができた油層基材/水 $(3 / 7$ $\mathrm{vol} / \mathrm{vol})$ の割合になるように両者を混合して均質化し た。

すなわち, $50 \mathrm{~mL}$ のねじふた付き試験管に油層基材
を所定量採取し、これに Tween \# 20 を自動酸化基質に 対して $5 \%$ になるように加え, 高速ディスパーサー T25-S2 型（独国 JANKE \& KUNKEL GMBH \& CO. 製) を用いて室温下に乳化剂が油層基材に均一に なるまで $9500 \mathrm{rpm}$ でホモジナイズした。

次に, 所定量のイオン交換水を加えて, 再び高速ディ スパーサーを用いて室温下に $10 \mathrm{~min}, 9500 \mathrm{rpm}$ でホモ ジナイズした。

\section{$2 \cdot 3$ 自動酸化試験}

精製魚油にリン脂質を $0,5,20 \%$ 濃度に添加した系と Toc を $0.05 \%$ 加えた精製魚油にリン脂質を $0,1,5,10$, $20 \%$ 濃度に添加した系について, 乳化系の自動酸化試 験を $30^{\circ} \mathrm{C}$ 恒温槽中で行い, 経時的に過酸化物価 $(\mathrm{PV})$, カルボニル価 (CV), DHA 残存量, Toc 残存量などを 測定した。また, 比較のために非水系の自動酸化試験も 必要に応じて乳化系に準じた条件下に行った。

さらに, 脂溶性ラジカル開始剂として 2,2 '-アゾビス イソブチロニトリル (AIBN), あるいは水溶性ラジカル 開始剤として 2,2 '-アゾビス (2-アミジノプロパン) ヒ ドロクロリド $(\mathrm{AAPH})$ の所定量を精製魚油および $0.05 \%$ Toc 添加精製魚油に加えた 2 系にそれぞれリン 脂質を $20 \%$ 添加した場合の酸化防止作用と相乗作用に ついても検討した。なお，この自動酸化試験においては 脂肪酸組成を考慮して, 対照実験系にはリン脂質の代わ りに大豆油を $20 \%$ 添加した。

\section{$2 \cdot 4$ 分 析 法}

自動酸化試験の評価を行うために, PV の測定は電位 差滴定法 ${ }^{8)}$,9) に基づいて行った。すなわち, 電位の測 定および記録は三菱化学(株)製自動滴定装置 GT-05 型 にグラフィックプリンター CP-80 TYPE-1 を接続し, 電極として同社製の白金複合電極 GT-01 型を用いた。

$\mathrm{CV}$ の測定は基準油脂分析試験法記載の方法 ${ }^{10)}$ に 従って行い, 吸光度の測定には日本分光(株)製の Ubest -50 型分光光度計を使用した。自動酸化基質の脂肪酸組 成の分析は構成脂肪酸を Jham らの方法 ${ }^{11)}$ に従ってメ チルエステル化した後, 島津製作所製ガスクロマトグラ フ GC-17A 型に結合型キャピラリーカラム HR-SS-10 $(0.25 \mathrm{mmi}$.d. $\times 25 \mathrm{~m})$ を接続して, 昇温 GLC 分析を 行った。自動酸化基質に添加した Toc の定量は日本分 光(株)製 BIP-1 型に同社製 FP-210 型蛍光検出器 $(\mathrm{Ex}$ : $295 \mathrm{~nm}, \mathrm{Em}: 325 \mathrm{~nm}$ ) を接続して HPLC 分析を 行った ${ }^{12) \sim 15) 。 ~}$

なお, 乳化系の自動酸化基質の諸分析に当たっては, あらかじめクロロホルムを用いて脂質を抽出し, 硫酸ナ トリウム (無水物) により脱水した後, 脱溶媒したもの を用いた。

リン脂質の組成分析は装置として(株)ヤトロン製イア トロスキャン $\mathrm{MK}-5$ 型を, 固定層として同社製シリ 
カゲル焼結クロマロッド S- IIIを, 一次展開溶媒として ベンゼン/クロロホルム/酶酸 $(35 / 15 / 1 \mathrm{vol} / \mathrm{vol} / \mathrm{vol})$, 二 次展開溶媒としてクロロホルム/メタノール/水 $(75 / 25 /$ $2 \mathrm{vol} / \mathrm{vol} / \mathrm{vol}$ ) を用いた TLC-FID 分析によった。

\section{3 結果と考察}

\section{$3 \cdot 1$ 自動酸化試料の性状}

自動酸化基質として用いた精製魚油と酸化防止作用あ るいは Toc に対する相乗効果を検討するために用いた 3 種のリン脂質の性状を Table 1 に示した。

なお，カラム分画前の魚油の PV と Toc 含有量はそ れぞれ $2.06 \mathrm{meq} / \mathrm{kg}$ と $51.22 \mu \mathrm{g} / \mathrm{g}$ oil であったが, カ ラム分画後の精製魚油の PV は $0.67 \mathrm{meq} / \mathrm{kg}$ であり, Toc は完全に除去されていた。また, 精製魚油の回収 率は $95.1 \%$ であった。

\section{$3 \cdot 2$ 非水系と Tween \# 20 乳化系の自動酸化挙動の 比較}

乳化系におけるリン脂質の酸化防止作用を検討するに 先立って, 非水系と Tween \# 20 を用いた乳化系におけ る精製魚油の自動酸化挙動について比較した。

その結果, Fig. 1 に示したように非水系の方が乳化系 に比べて幾分酸化されやすいものの, 精製魚油の PV の経時変化に大きな差は認められなかった。

また，乳化系におけるリン脂質の Toc に対する相乗 効果を検討する前に, $0.05 \%$ の Toc を添加した精製魚 油の酸化安定性について, 非水系と乳化系で比較した結 果も Fig. 1 に併せて示した。これより, Toc 無添加の

Table 1 Fatty Acid Composition of Refined Fish Oil and Phospholipids (\%).

\begin{tabular}{c|c|c|c|c}
\hline \multirow{2}{*}{$\begin{array}{c}\text { Fatty } \\
\text { acid }\end{array}$} & \multirow{2}{*}{$\begin{array}{c}\text { Refined } \\
\text { Fish oil }\end{array}$} & \multicolumn{3}{|c}{ Phospholipids } \\
\cline { 3 - 5 } & $\mathrm{PC}$ & $\mathrm{PE}$ & $\mathrm{PC}-70$ \\
\hline $\mathrm{C}_{14: 0}$ & 9.8 & - & - & - \\
\hline $\mathrm{C}_{16: 0}$ & 21.5 & 13.4 & 19.0 & 15.8 \\
\hline $\mathrm{C}_{16: 1}$ & 13.1 & - & - & - \\
\hline $\mathrm{C}_{18: 0}$ & 5.9 & 2.0 & 0.4 & 2.8 \\
\hline $\mathrm{C}_{18: 1}$ & 11.0 & 9.5 & 7.2 & 9.5 \\
\hline $\mathrm{C}_{18: 2}$ & 2.3 & 65.7 & 63.0 & 64.5 \\
\hline $\mathrm{C}_{18: 3}$ & 4.0 & 9.4 & 10.4 & 7.4 \\
\hline $\mathrm{C}_{18: 4}$ & 2.9 & - & - & - \\
\hline $\mathrm{C}_{20: 4}$ & 1.7 & - & - & - \\
\hline $\mathrm{C}_{20: 5}$ & 12.9 & - & - & - \\
\hline $\mathrm{C}_{22: 6}$ & 6.0 & - & - & - \\
\hline Others & 8.9 & - & - & - \\
\hline
\end{tabular}

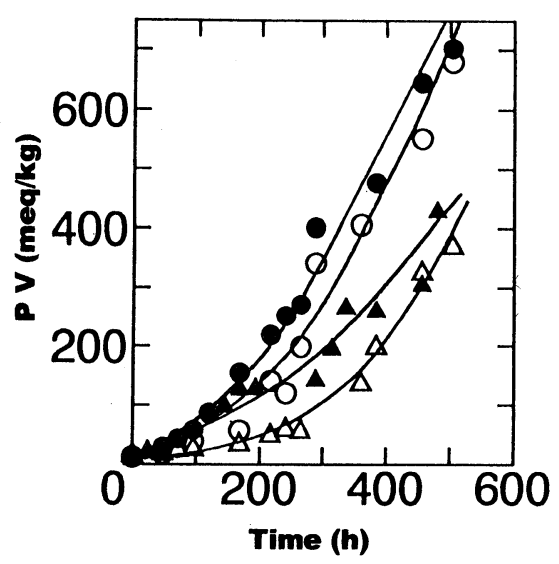

Fig. 1 Autoxidative Behavior of Refined Fish Oil with or without Tocopherol in Non-aqueous and Emulsifying Systems.

\footnotetext{
: without tocopherol in non-aqueous system

A: with tocopherol in non-aqueous system $O$ : without tocopherol in emulsifying system $\Delta:$ with tocopherol in emulsifying system
}

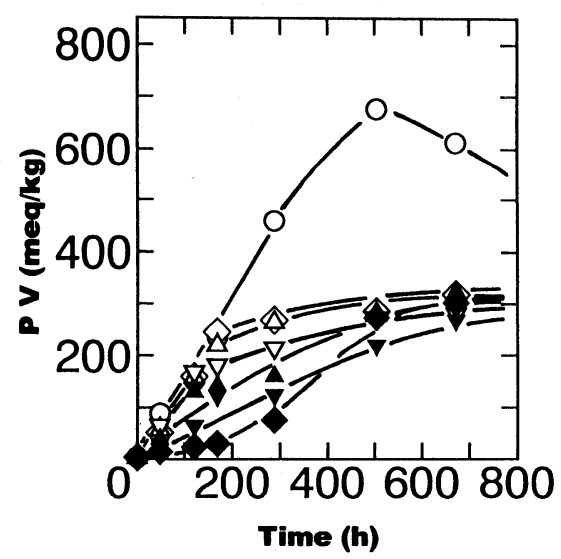

Fig. 2 Antioxidative Effect of Phospholipids on Refined Fish Oil in Emulsifying System.

\section{$\triangle:$ PC 5\% $\triangle:$ PC 20\% $\triangle$ : PE 5\% $\triangle$ : PE 20\% $\nabla:$ PC-70 5\% V:PC-70 20\% O:Control}

場合よりも酸化が抑制されるものの, 非水系と乳化系の いずれにおいても PV 変化はほぼ同様の傾向を示し た。それ故, 本実験で自動酸化基質として用いた精製魚 油の非水系と乳化系における酸化挙動に差は無いと判断 した。

\section{$3 \cdot 3$ 乳化系におけるリン脂質の酸化防止作用}

Tween \# 20 を用いた乳化系において，リン脂質とし て PC, PE, PC-70 を自動酸化基質に対して個々に $5 \%$ および $20 \%$ 添加した実験系の自動酸化試験を行い, そ 
の結果を Fig. 2 に示した。

Fig. 2 より，いずれのリン脂質添加系も対照実験系 に比較して PV の上昇が抑制され，酸化防止効果は $5 \%$ 添加系よりも $20 \%$ 添加系の方が顕著であった。

また, $\mathrm{PE}$ 添加系よりも $\mathrm{PC}$ および $\mathrm{PC}-70$ 添加系の 方が優れた効果を発揮した。

\section{4 乳化系におけるリン脂質の Toc に対する酸化防} 止相乗効果

Tween \# 20 乳化系において, $0.05 \%$ Toc 添加自動酸 化基質に 3 種のリン脂質を別々に $1 \%$ 添加して, 酸化防 止相乗効果を検討した。自動酸化試験中の PV の経時 変化は Fig. 3 に, 自動酸化基質に添加した Toc 量の経 時変化は Fig. 4 に, 精製魚油の構成脂肪酸であるDHA 残存率の経時変化は Fig. 5 にそれぞれ示した。

Fig. 3 に示したように, PC 添加系と PC-70 添加系 は精製魚油のみの対照実験系よりも PV の上昇が幾分 抑えられたものの, Toc 添加対照実験系の PV の上昇傾 向とほとんど差が無かった。

それに対して, PE 添加系は添加量が $1 \%$ であるにも かかわらず PV 上昇がかなり抑制され，Tocに対する酸 化防止相乗効果が明確に観察された。

この自動酸化基質に添加した Toc 量は Fig. 4 に示し たように, PE 添加系のみが対照実験系の約 2.8 倍に残 存期間を延長した。また, Fig. 5 に示したように, PV の上昇傾向亡 Toc の残存挙動を反映して, DHA の残存 率も PC 添加系と PC-70 添加系は対照実験系とまった く変わらず, 自動酸化開始約 $850 \mathrm{~h}$ 後にほぼ 0 になった のに対して, PE 添加系のみは $1200 \mathrm{~h}$ 後にも約 $50 \%$ が

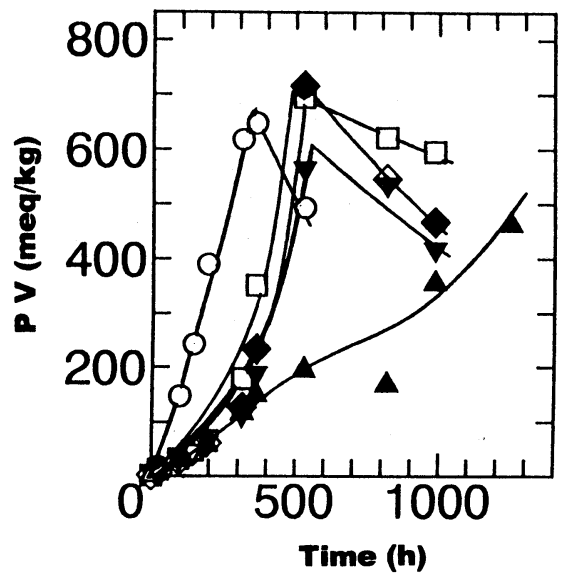

Fig. 3 Synergistic Effect of 1\% Phospholipids on 0.05\% Tocopherol Contained in Refined Fish Oil in Emulsifying System.

- : PC+Toc $\triangle$ : PE+Toc $\nabla$ : PC-70+Toc $\mathrm{O}:$ Control $\square:$ Toc

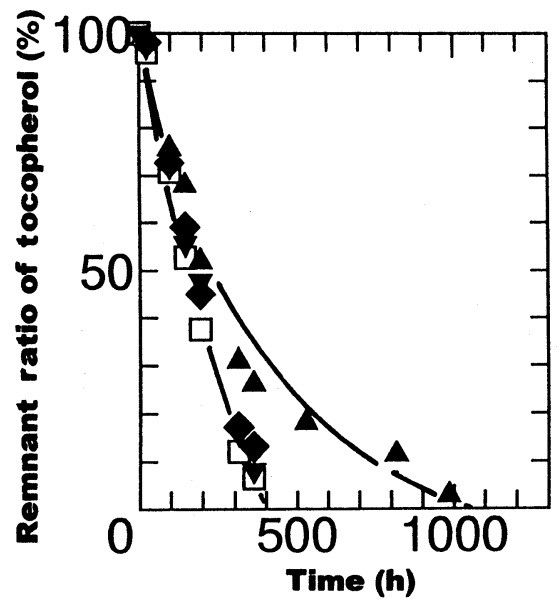

Fig. 4 Time Course of Tocopherol Level during Autoxidation of Refined Fish Oil with 1\% Phospholipids.
- : PC+Toc
$\nabla:$ PC-70+Toc
$\triangle$ : PE+Toc
$\square:$ Toc

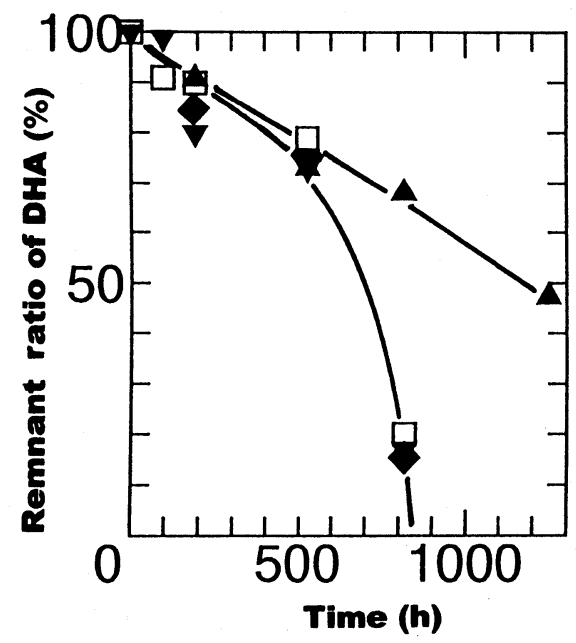

Fig. 5 Time Course of DHA Level during Autoxidation of Refined Fish Oil with $0.05 \%$ Tocopherol and 1\% Phospholipids.

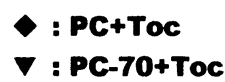

$\Delta$ : PE+TOC

$\square:$ Toc

残存していた。

次に, 精製魚油に Toc を $0.05 \%$ とリン脂質を $5 \%$ 添 加して同様の自動酸化実験を行った結果, Fig. 6 に示し たように $\mathrm{PE}$ 添加系の $\mathrm{PV}$ 上昇は大きく抑制された。

また，PC および PC-70 添加系も対照実験系として 設けた Toc 添加系あるいは精製魚油のみの系と比較し てPVの上昇が明らかに抑えられた。 


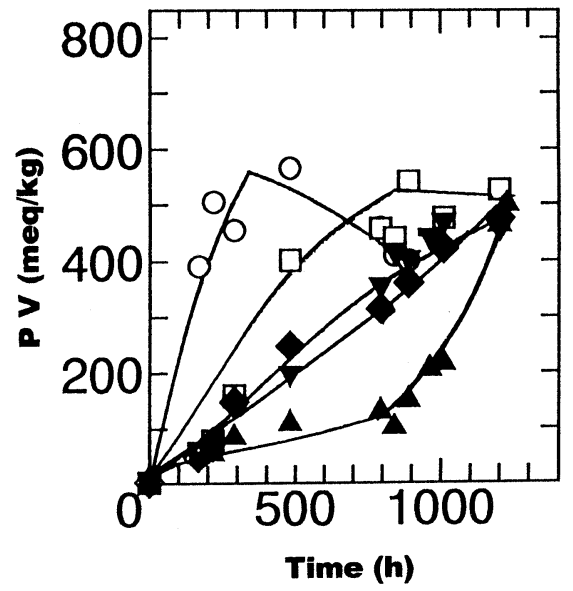

Fig. 6 Synergistic Effect of 5\% Phospholipids on 0.05\% Tocopherol Contained in Refined Fish Oil in Emulsifying System.

$\checkmark$ : PC+Toc $\triangle$ : PE+Toc $\nabla:$ PC-70+Toc
$O$ : Control $\square:$ Toc

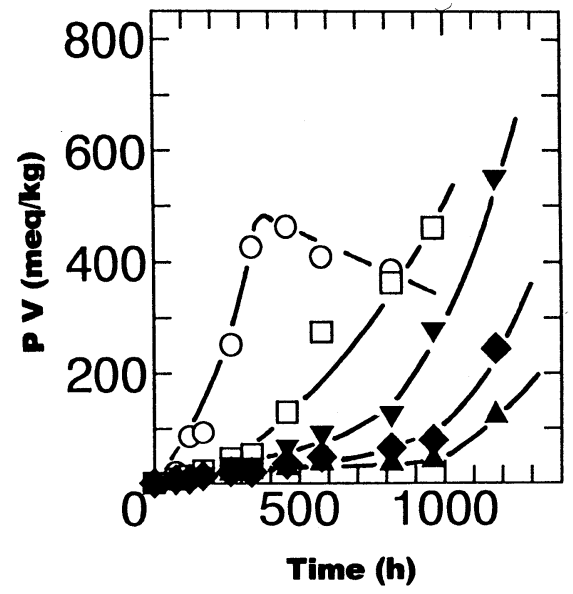

Fig. 7 Synergistic Effect of 10\% Phospholipids on 0.05\% Tocopherol Contained in Refined Fish Oil in Emulsifying System.

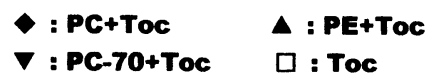

さらにリン脂質の添加量を $10 \%$ に増やした結果, Fig. 7 に示したように PE 添加系は約 $1000 \mathrm{~h}$ まで誘導 期が続き, PC および PC-70 添加系も PE 添加系の自 動酸化抑制作用に近づく傾向が認められた。なお，この 時の Toc と DHA の残存率の経時変化は Fig. 8, 9 に示 したように, PC および PE 添加系においていずれの残 存率も高かった。特に, PC を $10 \%$ 添加すると PE に 匹敵する Toc と DHA の残存効果が発揮されるように

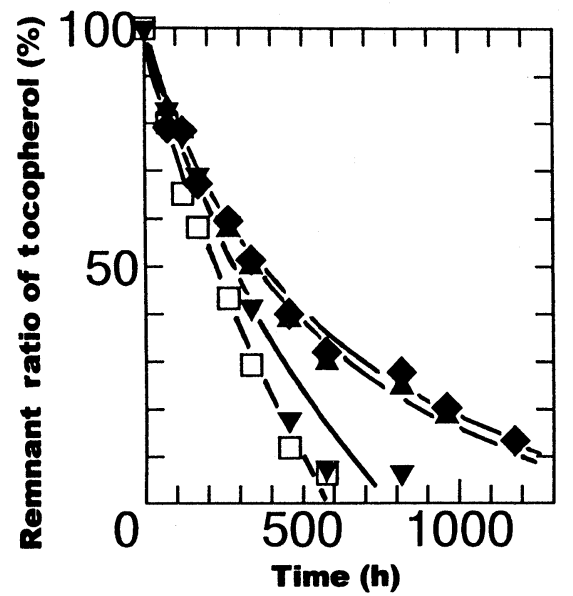

Fig. 8 Time Course of Tocopherol Level during Autoxidation of Refined Fish Oil with 10\% Phospholipids.
: PC+ToC
$\checkmark$ : PC-70+ToC
$\triangle$ : PE+Toc
$\square:$ Toc

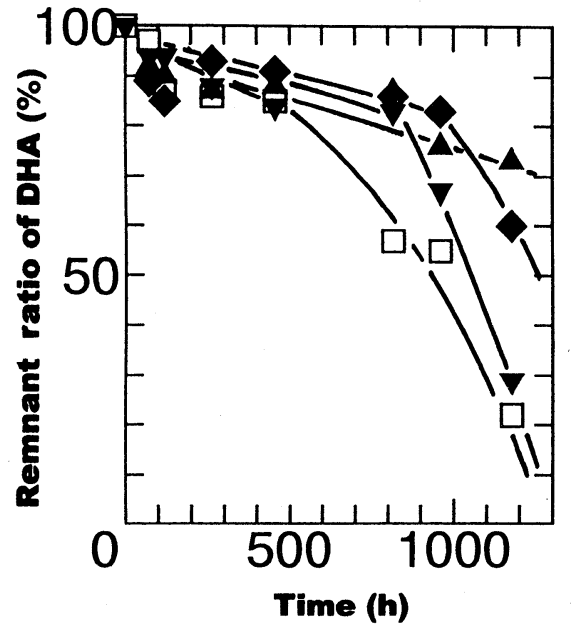

Fig. 9 Time Course of DHA Level during Autoxidation of Refined Fish Oil with $0.05 \%$ Tocopherol and 10\% Phospholipids.

\section{$\checkmark$ : PC+Toc $\triangle$ : PE+Toc \\ $\checkmark$ : PC-70+Toc $\square$ : Toc}

なり，注目に值する現象であった。

リン脂質の添加量を 20\%に増加させた場合, Fig. 10 に示したように $\mathrm{PC}$ 添加系と $\mathrm{PE}$ 添加系は $1000 \mathrm{~h}$ 以上 にわたり誘導期が継続し, 類似した PV の経時変化が 観察された。

また，PC-70を $20 \%$ 添加した系についても PV 上昇 がかなり抑制された。このように, Tween \# 20 を用い 


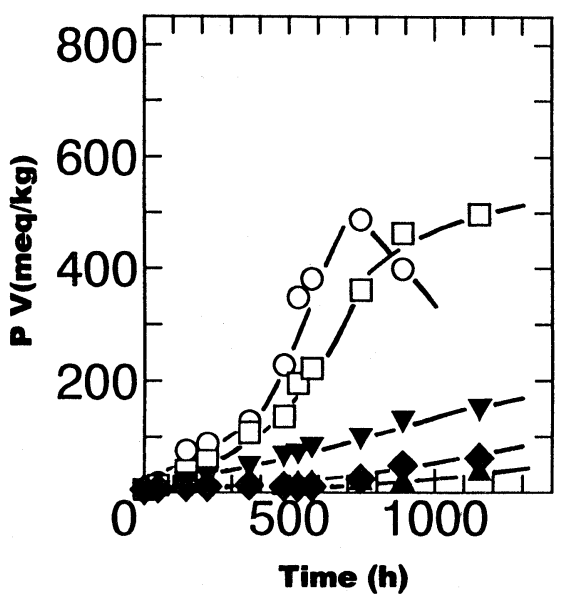

Fig. 10 Synergistic Effect of 20\% Phospholipids on $0.05 \%$ Tocopherol Contained in $\mathrm{Re}$ fined Fish Oil in Emulsifying System.
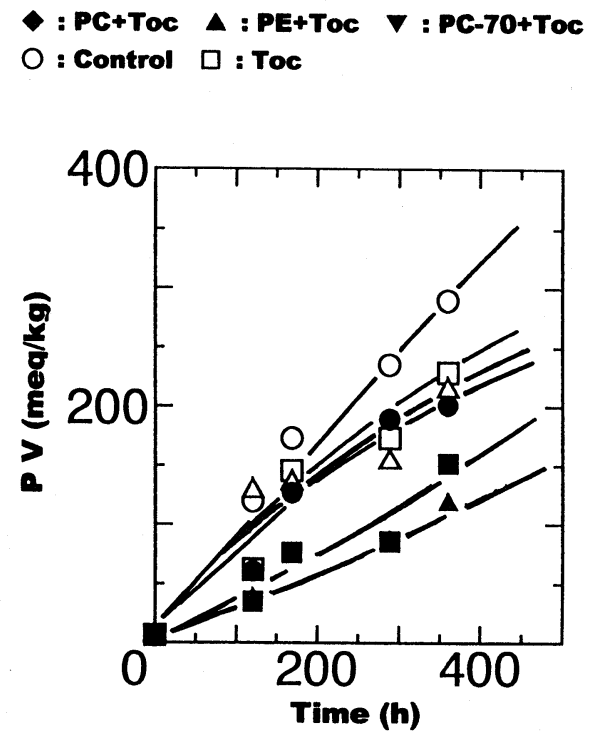

Fig. 11 Autoxidative Behavior of Refined Fish Oil with 20\% Phospholipids and Oil-soluble Radical Initiator.

\section{$1 \%$ Radical Initiator \\ O: Soybean Oil \\ ㅁ: PC \\ $\triangle:$ PE}

\section{$10 \%$ Radical Initiator O:Soybean Oil + Toc D: PC+Toc $\triangle:$ PE+TOC}

た本研究の乳化系において, リン脂質の添加量の増加に 伴い精製魚油に対する酸化防止作用が著しく向上するこ とが判明した。さらに, 脂溶性および水溶性ラジカル開 始剤を添加した乳化系におけるリン脂質 $20 \%$ 添加系の 自動酸化挙動を比較した結果, Fig. 11 に示したように 脂溶性ラジカルに対するリン脂質の添加は効果的で無 かったが, Fig. 12 に示したように水溶性ラジカルに対

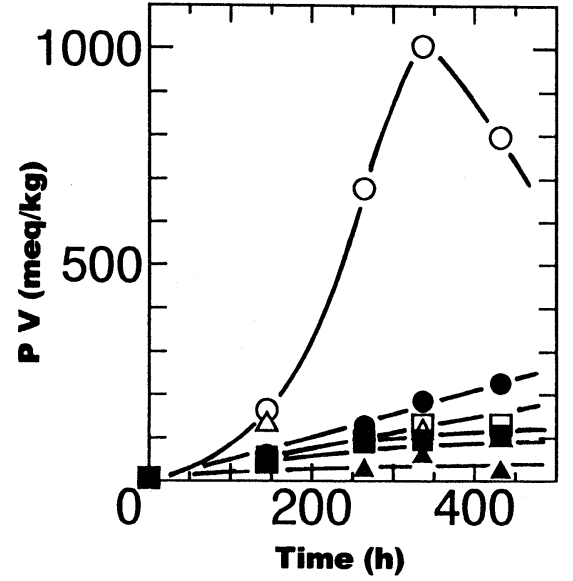

Fig. 12 Autoxidative Behavior of Refined Fish Oil with 20\% Phospholipids and Watersoluble Radical Initiator.

1\% Radical Initiator
O: Soybean Oil
प: PC
$\triangle:$ PE

\section{$10 \%$ Radical Initiator Q:Soybean Oil + Toc I: PC+Toc $\triangle$ : PE+ToC}

して, リン脂質は顕著な酸化防止作用および Toc に対 する相乗効果を示した。これは $\mathrm{O} / \mathrm{W}$ 型乳化系におい て, PC のホスホリルコリン部分や PE のホスホリルエ タノールアミン部分が親水基として水層側に配列して, 水溶性ラジカルを電荷移動型複合体としてトラップする のではないかと考えられた。

なお，本実験は Tween \# 20 と所定量のリン脂質を用 いて調製した安定な $\mathrm{O} / \mathrm{W}$ 型エマルションについて，リ ン脂質の酸化防止作用と Toc に対する相乗効果を比較 したものであるが, リン脂質が乳化剂として機能する場 合に, 添加量によってエマルションの構造変化が起こ り，物性へ影響することも考えられるため，それについ ては今後検討したいと考えている。

以上のことから, 乳化系におけるリン脂質の酸化防止 作用あるいは Toc に対する相乗効果は水溶性フリーラ ジカルに対して効果的であり, リン脂質が水層で発生し たフリーラジカルを捕そくする作用を有するか，あるい は水溶性フリーラジカルと Toc の反応性を高めるもの と推察された。

\section{4 総 括}

大豆リン脂質から調製した $\mathrm{PC}, \mathrm{PE}$ 及び PC-70 の酸 化防止作用之 Toc に対する酸化防止相乗作用について, $30^{\circ} \mathrm{C}$ の自動酸化条件下に精製魚油/水 $(3 / 7 \mathrm{vol} / \mathrm{vol})$ の 乳化系を用いて検討した。その結果, 各リン脂質の酸化 防止作用は添加量に伴って増大し, 試験したリン脂質の 中で PC の活性が最も高かった。Toc に対する酸化防 
止相乗効果は油層基材に対して $20 \%$ 添加した場合に最 も顕著であり, 続いて $10 \%>5 \%>1 \%$ であった。また, $\mathrm{PE}$ は添加量がいずれの場合も $\mathrm{PC} や \mathrm{PC}-70$ の対応す る添加量よりも優れた相乗効果を示した。さらに, リン 脂質の酸化防止効果は脂溶性ラジカル開始剂添加系より も, 水溶性ラジカル開始剤添加系において強く発揮され た。

（受付 : 1996 年 7 月 18 日, 受理 : 1996 年 9 月 3 日)

\section{文献}

1）矢澤一良, 影山治夫, 油化学, 40, 974 (1991)。

2) 鬼頭 誠, 油化学, 40, 838 (1991).

3）大澤俊彦, 油化学, 38, 839 (1989).

4) 菊崎泰枝, 河合弥生, 原 早苗, 中谷延二, 福田清司, 第 50 回日本栄養 - 食糧学会大会講演要旨集, p. 94 (1996).

5) K. Miyashita, E. Nara, T. Ota, Biosci. Biotech. Biochem., 57, 1638 (1993).
6) K. Miyashita, E. Nara, T. Ota, Biosci. Biotech. Biochem., 58, 1772 (1994).

7） M. Kates 著, 山川民夫, 斎藤国彦, 林陽訳, “生 化学実験法 5 , 脂質研究法”, 東京化学同人 (1975), p. 103.

8) S. Hara, Y. Totani, J. Am. Oil Chem. Soc., 65, 1948 (1988).

9) S. Hara, Y. Kuroda, S. Nakagawa, Y. Totani, $J$. Jpn. Oil Chem. Soc., 43, 18 (1994).

10）日本油化学協会編“基準油脂分析試験法” 2.4.22-73 (1990).

11) G.N. Jham, F.F.F. Teles, L.G. Camps, J. Am. Oil Chem. Soc., 59, 132 (1982).

12）阿部晧一, 勝井五一郎, 栄養と食糧, 28, 453 (1975).

13）阿部皓一, 大前雅彦, 勝井五一郎, ビタミン, 50, 453 (1976).

14) K. Abe, U. Yuguchi, G. Katsui, J. Nutr. Sci. Vitaminol., 21, 183 (1975).

15）小川博史, 原 節子, 戸谷洋一郎, 油化学, 44, 1055 (1995). 


\title{
日本油化学会誌本号掲載 論文要旨
}

\begin{tabular}{|c|c|}
\hline [総説 $]$ & $\begin{array}{c}\text { 高度不飽和油脂の自動酸化に対する } \\
\text { 含空素リン脂質の酸化防止効果 }\end{array}$ \\
\hline & $\begin{array}{c}\text { 戸 谷 洋一郎 } \\
\text { 成蹊大学工学部 ( } 180 \text { 東京都武蔵野市吉祥寺北町 3-3-1) }\end{array}$ \\
\hline $\begin{array}{l}\text { 非水系 } \\
\text { ジルエタ } \\
\text { チルエタ } \\
\text { (PS), エま } \\
\text { 価した。 } \\
\text { 試験した } \\
\text { ながら, } \\
\text { 察された。 } \\
\text { えられた。 }\end{array}$ & 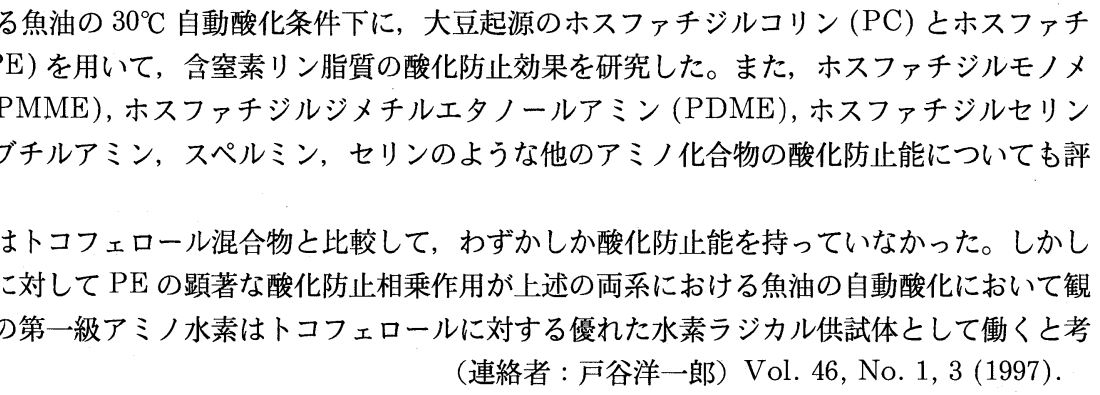 \\
\hline
\end{tabular}

\section{[報文］チューリップ (Tulipa gesneriana L.)}

\section{花弁抽出物質の酸化防止性及び抗菌性について}

\author{
小 柳 津 周*1 • 荻 原 博 和 ${ }^{* 2}$ 成 瀬 宇 平*3 \\ *1 武咸野栄養専門学校 (下171 果京都豊島区南池袋 3-12-5) \\ $* 2$ 日本大学生物資源科学部 ( 1154 東京都世田谷区下馬 3-34-1) \\ *3 鎌倉女子大学 (干247 神奈川県鎌倉市岩瀬 1420)
}

植物には，色素やビタミン剤（ $\beta$-カロテンやビタミン E など）が多様に存在し，それらが生理活性作用に深く 関与していることが知られるようになった。

本研究では, チューリップを選択した。試料はチューリップ花弁から水とエタノールで抽出した，そして酸化防 止性と抗菌性を評価した。抽出物質は, 含有量, 色調, $\mathrm{pH}, \alpha$-トコフェロール量及び吸収スペクトルをそれぞれ 測定した。酸化防止性は, 水抽出物質で赤色花弁 >白色花弁 > 黄色花弁 > 紫色花弁 > 桃色花弁, エ夕ノール抽出物 質では紫色花弁 $=$ 黄色花弁 $>$ 白色花弁 $>$ 赤色花弁 $>$ 桃色花弁の順であった。さらに，抗菌性は水及びエタノール抽 出物質ともに同様の効果を示した。

(連絡者：小柳津周）Vol. 46, No. 1, 17 (1997).

\section{[報文］＼cjkstart乳化系におけるリン脂質の酸化防止効果}

\author{
渡邊 将 人・原節子・戸 谷 洋一郎 \\ 成蹊大学工学部 (T180 東京都武蔵野市吉祥寺北町 3-3-1)
}

大豆リン脂質から調製したホスファチジルコリン $(\mathrm{PC})$, ホスファチジルエタノールアミン $(\mathrm{PE})$ 及び $\mathrm{PC}$ 濃縮 リン脂質 (PC-70) の酸化防止作用とトコフェロールに対する酸化防止相乗効果について, $30^{\circ} \mathrm{C}$ の自動酸化条件下 に精製魚油/水 $(3 / 7, \mathrm{vol} / \mathrm{vol})$ の乳化系を用いて検討した。 
その結果, 各リン脂質の酸化防止作用は添加量に伴って増大し, 試験したリン脂質の中で $\mathrm{PC}$ の活性が最も高 かった。

Toc に対する酸化防止相乗効果は油層基材に対して $20 \%$ 添加すると顕著であり，続いて $10 \%>5 \%>1 \%$ であっ た。また, PE は添加量がいずれの場合も PCや PC-70 の対応する添加量よりも優れた相乗効果を示した。

さらに, リン脂質の酸化防止効果は脂溶性ラジカル開始剂添加系よりも, 水溶性ラジカル開始剂添加系において 強く発揮された。

（連絡者 : 戸谷洋一郎）Vol. 46, No. 1, 21 (1977).

\title{
[報文］セトウチマイマイのスフィンゴ脂質（第 2 報） 内臓部スフィンゴ脂質の分枝長鎖塩基
}

\author{
岸 根 秀 樹・林陽 \\ 近畿大学理工学部化学教室 (宁577 東大阪市小若江 3-4-1)
}

セトウチマイマイ (Euhadra hickonis) における脂質二重層内のスフィンゴ脂質の分枝長鎖塩基の構造とその 物理的な性質について検討した。 GC および GC/MS の分析結果から，セトウチマイマイの主な分枝長鎖塩基の 構造は 2-アミノ-16-メチルオクタデセン-1,3-ジオールであった。

スフィンゴ脂質の分枝長鎖塩基から誘導したアルデヒドとメチルエーテルのマススペクトルで観察される $\mathrm{m} / \mathrm{z}$ 56 と 70 のフラグメントイオンが, それぞれイソとアンテイソ構造であることを分子軌道計算 (AM 1 と PM 3) に よるフラグメントイオンの生成熱から示した。また, MM 2 を用いてスフィンゴ脂質の長鎖塩基より誘導したメチ ルエーテルと脂肪酸メチルエステルの分子力学計算を行った。その結果, 長鎖塩基の炭化水素鎖内のアンテイソ構 造が脂質二重層の流動性を増加させる知見が得られた。

腹足綱動物における有肺類と後さい(鰓)類の進化と生物学的見地から, セトウチマイマイ (有肺類) と後鰓類の アマクサアメフラシ (Aplysia juliana) のスフィンゴ脂質の長鎖塩基についても比較検討した。

（連絡者：林陽）Vol. 46, No. 1, 29 (1997).

\section{[報文 $\quad$ テングニシのスフィンゴ脂質}

内臓部のセラミドモノヘキソシドとセラミドアミノエチルホスホネート

$$
\begin{aligned}
& \text { 三 島 芳 博*1 ・岸 根 秀 樹*2 ・林晹*2 } \\
& \text { *1 近畿大学九州工学部工業化学科 ( } 7820 \text { 福岡県飯塚市柏の森) } \\
& \text { *2 近畿大学理工学部化学教室 (干577 東大阪市小若江 3-4-1) }
\end{aligned}
$$

テングニシ (Hemifusus ternatanus) の内臓部より得られたセラミドモノヘキソシド (CMH) とスフィンゴホ スホノ脂質 $(\mathrm{SPnL})$ の分析を行った。

テングニシは動物の分類において前鰓亜綱に属し，進化や生物学的な面においても一般的な海産の貝である。

アセトンで単純脂質を抽出した後にクロロホルムーメタノール $(2: 1$, by vol) で複合脂質を抽出し, 主要なス フィンゴ脂質である $\mathrm{CMH}, \mathrm{SPnL}$ をケイ酸カラムクロマトグラフ法により分離, 精製した。得られたスフィンゴ 脂質は TLC, $\mathrm{FAB} / \mathrm{MS}$, 分解生成物の分析, そして糖, 長鎖塩基, リン, 脂肪酸エステルの定量分析により同定 した。

水溶性成分である糖の GC 分析の結果より CMH はほとんどガラクトシルセラミド (Gal-Cer) で構成されてい る事がわかった。SPnL はセラミドアミノエチルホスホネート (CAEP) とセラミド-N-メチルアミノエチルホス ホネート (CMAEP) の比は FAB/MS の正イオンモードで約 $73: 27$, 負イオンモードで約 $93: 7$ で構成されてい た。GC 分析から水溶性成分はほとんど 2-アミノエチルホスホン酸であった。 